\title{
Examination of Demographic Characteristics of Drug and Corrosive Poisonings, Morbidity and Mortality in Children in Terms of Emergency Department and Pediatric Surgery
}

\author{
Abuzer Coskun'*, MD, Cengiz Güney², Assoc. Professor \\ ${ }^{1}$ SBU Istanbul Bağcılar Training and Research Hospital, Emergency Medicine Clinic, Istanbul, Turkey \\ ${ }^{2}$ Cumhuriyet University Medical Faculty, Department of Pediatric Surgery, Sivas, Turkey
}

*Corresponding author: Abuzer Coskun, MD SBÜ İstanbul Bağcılar Eğitim ve Araștırma Hastanesi, Acil Tıp Kliniği, Merkez Ma-

hallesi Dr. Sadık AHMET Caddesi, Bacılar, İstanbul, Turkey

\begin{tabular}{|c|c|}
\hline ARTICLE INFO & Abstract \\
\hline 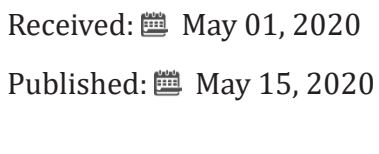 & $\begin{array}{l}\text { Citation: Coskun A, Güney C. Examination of Demographic Characteristics of Drug } \\
\text { and Corrosive Poisonings, Morbidity and Mortality in Children in Terms of Emergency } \\
\text { Department and Pediatric Surgery. Biomed J Sci \& Tech Res 27(4)-2020. BJSTR. } \\
\text { MS.ID.004538. }\end{array}$ \\
\hline
\end{tabular}

\section{Introduction}

Poisoning is a condition that kills or damages the organism by the introduction of toxic substances into the body and is among the preventable causes of morbidity and mortality among childhood emergency diseases [1,2]. Although the advancing technology, conscious nutrition, and preventive medicine practices become widespread, it still stands out among the causes of death [3]. The annual incidence of suicidal or accidental poisoning is between $0.02-0.93 \%$ in developed countries and between $0.46-1.57 \%$ in developing countries [4]. $80 \%$ of poisonings are in children under 5 years of age. $2 \%$ of children's deaths in developed countries and more than $5 \%$ in developing countries are due to poisoning [5]. Drug poisoning, which is one of the important reasons for admission to pediatric emergency departments, is an important problem both in terms of public health and socioeconomics and the admissions with this cause continue to increase around the world. Early diagnosis and treatment are important because of the high morbidity and mortality rates in the late intervention [6]. To reduce the morbidity and mortality rates of poisoning cases in the pediatric age group, it is important to take necessary precautions and establish treatment protocols as well as the knowledge of pharmacological characteristics. In this study, we aimed to reveal the effects of drug and non-drug poisonings and to contribute to the future treatment algorithm.

\section{Materials and Methods \\ Study Design and Population}

A total of 1678 children who were brought to the emergency department with drug poisoning and caustic substance ingestion between January 2010 and December 2018, who underwent outpatient and inpatient follow-up and whose file information could be accessed were included in this retrospective cohort study. Food and plant poisonings, ingestion of unknown agents, patients without consent for the study, patients under 1 year and above 16 years of age were excluded from the study. The data of the patients were evaluated in terms of age, sex, poisoning agent, provided treatments and prognoses. 'Medical records' or other emergency outpatient records, paramedic reports, inpatient charts, nursing notes, and other clinical records. Studies based on death certificates, forensic reports or other public records and all studies based on animal or laboratory research were excluded. Patients poisoned by drug and non-drug agents were divided into three groups as 1-5, 6-11 and over 12 years of age. The causes of poisoning (accidental or suicidal), clinical findings and treatments were recorded. Substances with known pharmacological agents were divided into 10 groups. Patients with multiple substance exposure were also not included in the single substance exposure group. Zargar [7] 
classification was used to determine the degree of damage to the esophagus due to corrosive substance ingestion (Table 1).

Table 1: Zargar Classification according to endoscopic grading.

\begin{tabular}{|c|c|}
\hline Zargar Classification & Explanation \\
\hline Grade 0 & Normal mucosa \\
\hline Grade I & Mucous edema and erythema \\
\hline Grade IIA & $\begin{array}{c}\text { Bleeding, erosion, blisters, } \\
\text { superficial ulcers }\end{array}$ \\
\hline Grade IIB & Environmental lesions \\
\hline Grade IIIA & $\begin{array}{c}\text { Focus deep gray or brownish-black } \\
\text { ulcers }\end{array}$ \\
\hline Grade IIIB & $\begin{array}{c}\text { Wide deep gray or brownish-black } \\
\text { ulcers }\end{array}$ \\
\hline Grade IV & Perforation \\
\hline
\end{tabular}

\section{Statistical Analysis}

The data obtained from this study were analyzed by SPSS 20.0 (SPSS Inc., Chicago, IL, USA) software package. While investigating the state of variables' derivation from normal distribution Shapiro Wilk test was used due to the number of units. When analyzing the differences between the groups, Mann Whitney U Tests were used because the variables did not show normal distribution. The chi-square analysis was performed to examine the relationships between the groups of nominal variables. In cases where the expected values in the cells of $2 \times 2$ tables did not have sufficient volume, Fisher's Exact Test was used, and in the RxC tables, Spearman Correlation analysis was performed with the help of Monte Carlo Simulation. Besides, Cox regression analysis was used for univariate and multivariate analysis of variables. Univariate analysis was used to measure the relationship of variables with poisoning. The variables that were found to be statistically significant in the univariate analysis were used in the multivariate Cox regression risk model with the forward stepwise method to determine the independent prognostic factor. When interpreting the results, the significance level was set at 0.05 and $P$ values less than 0.05 were considered as statistically significant.

\section{Results}

The mean age of 1678 patients admitted to the emergency department for poisoning was $8.32 \pm 3.23$ years (1-15 years). $54.3 \%$ of the cases were girls, $45.7 \%$ were boys and the ratio was G/B: 1.18/1. The mean age of the patients who accidentally took corrosive substance or drug (ACT) was $6.39 \pm 2.21$ and the mean age of the patients who suicidally took the corrosive substance or drug (SCT) was $11.5 \pm 1.83$. The baseline and laboratory characteristics of the patients are shown in Table $2.19 \%$ of the cases were under 5 years, $61 \%$ were between $6-11$ years and $20 \%$ were over 12 years of age. While $94.6 \%$ of the poisoning cases were caused by drugs, $5.4 \%$ were caused by non-drug substances. Poisoning by drugs and non-drug agents was most commonly observed in patients aged 6-11 years. It was found that $62.2 \%$ (1043) of the cases were accidental and $37.8 \%$ (635) were suicidal. While the most frequent poisoning cases were between the ages of 6-11, the SCT group consisted of patients aged 12 years and older. Poisoning by the single agent was most common between the ages of 6-11, whereas poisoning by multiple agents was more common in patients aged 12 years and older.

Table 2: Baseline characteristics of study patients.

\begin{tabular}{|c|c|c|c|c|c|}
\hline \multirow{2}{*}{\multicolumn{2}{|c|}{ All patients }} & \multirow{3}{*}{ Accident } & \multicolumn{3}{|c|}{ Cause of Poisoning Patients with } \\
\hline & & & \multicolumn{3}{|c|}{ Suicide } \\
\hline Basaline Characteristcis & & & & & $\mathrm{p}$-value \\
\hline Age, mean $\pm S D$, yr & $8.32 \pm 3.23$ & $6.39 \pm 2.21$ & $11.50 \pm 1.83$ & $\mathrm{Z}=-32.333$ & 0.001 \\
\hline Sex, Female/Male & $911 / 767$ & $746 / 297$ & $165 / 470$ & $\mathrm{X} 2=329.857$ & 0.001 \\
\hline Labaratory Finding & & & & $\mathrm{Z}$ & \\
\hline $\mathrm{BS}, \mathrm{mg} / \mathrm{dL}$ & $123.16 \pm 47,20$ & $123.70 \pm 50.26$ & $109.27 \pm 41.73$ & -2.042 & 0.041 \\
\hline ALT, mg/dL & $25.87 \pm 21.97$ & $26.28 \pm 23.03$ & $25.19 \pm 20.10$ & -1.085 & 0.278 \\
\hline AST, mg/dL & $24.52 \pm 23.10$ & $24.93 \pm 24.11$ & $23.84 \pm 21.32$ & -0.674 & 0.5 \\
\hline ALP, mg/dL & $98.70 \pm 51.78$ & $98.84 \pm 49.62$ & $98.47 \pm 55.19$ & -1.064 & 0.287 \\
\hline $\mathrm{CRP}, \mathrm{mg} / \mathrm{dL}$ & $3.40 \pm 5.03$ & $3.42 \pm 4.70$ & $3.36 \pm 5.53$ & -3.45 & 0.001 \\
\hline WBC, $10^{\wedge} 3 / \mathrm{uL}$ & $9.80 \pm 3.72$ & $9.84 \pm 3.57$ & $9.73 \pm 3.96$ & -1.627 & 0.104 \\
\hline MCV, fL & $87.49 \pm 7.12$ & $87.29 \pm 7.42$ & $87.82 \pm 6.60$ & -1.101 & 0.312 \\
\hline MCH, pg & $29.32 \pm 2.35$ & $29.34 \pm 2.30$ & $29.29 \pm 2.26$ & -0.768 & 0.443 \\
\hline $\mathrm{MCHC}, \mathrm{g} / \mathrm{dL}$ & $33.38 \pm 3.37$ & $33.38 \pm 3.11$ & $33.37 \pm 3.77$ & -0.008 & 0.994 \\
\hline RDW, $\%$ & $14.75 \pm 1.91$ & $14.87 \pm 2.09$ & $14.56 \pm 1.57$ & -2.822 & 0.001 \\
\hline MPV, fL & $8.42 \pm 1.08$ & $8.38 \pm 1.08$ & $8.48 \pm 1.08$ & -2.168 & 0.03 \\
\hline $\mathrm{P}, \mathrm{mmol} / \mathrm{L}$ & $3.90 \pm 0.86$ & $3.57 \pm 0.98$ & $4.44 \pm 0.35$ & -2.131 & 0.033 \\
\hline
\end{tabular}




\begin{tabular}{|c|c|c|c|c|c|}
\hline $\mathrm{Na}+\mathrm{mmol} / \mathrm{L}$ & $137.65 \pm 10.01$ & $137.80 \pm 10.58$ & $137.41 \pm 9.02$ & -2.072 & 0.038 \\
\hline $\mathrm{Cl}, \mathrm{mmol} / \mathrm{L}$ & $99.16 \pm 9.14$ & $99.42 \pm 8.69$ & $98.74 \pm 9.82$ & -0.93 & 0.353 \\
\hline $\mathrm{K}+\mathrm{mmol} / \mathrm{L}$ & $3.56 \pm 0.67$ & $4.65 \pm 0.64$ & $4.65 \pm 0.71$ & -0.425 & 0.671 \\
\hline $\mathrm{Ca}++, \mathrm{mmol} / \mathrm{L}$ & $9.71 \pm 5.62$ & $9.51 \pm 3.87$ & $10.04 \pm 4.37$ & -1.049 & 0.294 \\
\hline
\end{tabular}

Note: Yr: year, SD: Standard deviation, BS: Blood Sugar , ALT: Alanın Aminotransferaz, AST: Aspartat Aminotransferaz, ALP: Alkalen Fosfataz, CRP: C reactive protein, WBC: White Blood Cell, MCV; Mean Corpuscular Volume; MCH: Mean Corpuscular Hemoglobine; MCHC:Mean Corpuscular Hemoglobin Concentration; RDW: Red cell distrubition width; MPV:Mean Platelate Volum, P: phosphorus, Na+: Sodium, Cl: Chlorine, $\mathrm{K}^{+}$: Potassium, $\mathrm{Ca}++$ : Calcium * $<<0.05$

Analgesics were the leading agents responsible for drug poisoning, followed by antidepressants. Paracetamol was the most common poisoning agent in the analgesic group and was most frequently seen between the ages of 6-11. In drug poisonings according to age, it was found that analgesic / antipyretic group poisoning was the most common in all age groups. Antidepressants were the second most common cause of poisoning in the 6-11 age group. Non-drug poisonings (organophosphates, corrosive substances) were also most frequently observed between the ages of 6-11. Mortality was most commonly observed in the 1-5 age group and it was observed in $5(0.3 \%)$ patients in this group.

Table 3: Chi-square test according to the variables of age groups.
When the relationship between age groups and endoscopic staging of esophageal damage after corrosive substance exposure was examined, grade 1 damage was the most common. Grade 1 damage was most commonly seen in the 6-11 age group. Those taking multiple drugs were not included in single groups (Table 3). Girl patients were more in the accidental poisoning group whereas boy patients were the majority in the SCT group. Patients who were poisoned by multiple agents were more in the SCT group. Analgesic / antipyretic drugs were the leading drugs used for suicidal purposes, followed by antidepressant drugs.

\begin{tabular}{|c|c|c|c|c|c|c|}
\hline \multicolumn{7}{|c|}{ Age Groups } \\
\hline & & $1-5$ age & 6-11 age & $12+$ age & & \\
\hline & & n(\%) & n(\%) & n(\%) & $\chi^{2}$ & p-value \\
\hline \multirow[t]{2}{*}{ Gender } & Female & $224(13.3)$ & $623(37.1)$ & $64(3.8)$ & 219.392 & 0.001 \\
\hline & Male & $94(5.6)$ & $401(23.9)$ & $272(16.2)$ & & \\
\hline \multirow[t]{2}{*}{ Drug intake } & Single & $315(18.8)$ & $1015(60.5)$ & $113(6.7)$ & 956.531 & 0.001 \\
\hline & Multiple & $3(0.2)$ & $9(0.5)$ & $223(13.3)$ & & \\
\hline \multirow[t]{2}{*}{$\mathrm{CP}$} & Accident & $318(19.0)$ & $937(55.8)$ & $49(2.9)$ & 976.743 & 0.001 \\
\hline & Suicide & $0(0)$ & $87(5.2)$ & $287(17.1)$ & & \\
\hline \multirow[t]{2}{*}{ Mortality } & No & $313(18.7)$ & $1022(60.9)$ & $335(20.0)$ & 9.981 & 0.007 \\
\hline & Yes & $5(0.3)$ & $2(0.1)$ & $1(0.1)$ & & \\
\hline \multirow[t]{10}{*}{ Drugs } & Paracetamol & $61(3.6)$ & $189(11.3)$ & $80(4.8)$ & 25.927 & 0.101 \\
\hline & Antidiabetic & $22(1.3)$ & $74(4.4)$ & $18(1.1)$ & & \\
\hline & Anticardiac & $43(2.6)$ & $134(8.0)$ & $43(2.6)$ & & \\
\hline & Asthma-COPD & $22(1.3)$ & $90(5.4)$ & $29(1.7)$ & & \\
\hline & Aspirin & $46(1.4)$ & $124(7.4)$ & $52(3.1)$ & & \\
\hline & NSAI & $24(1.4)$ & $69(4.1)$ & $27(1.6)$ & & \\
\hline & Antihypertensive & $24(3.9)$ & $69(4.1)$ & $9(0.5)$ & & \\
\hline & Antidepressant & $60(3.6)$ & $218(13.0)$ & $61(3.6)$ & & \\
\hline & Organophosphates & $7(0.4)$ & $9(0.5)$ & $6(0.4)$ & & \\
\hline & Corrosive & $9(0.5)$ & $48(2.9)$ & $11(0.7)$ & & \\
\hline \multirow[t]{6}{*}{ Corrosive } & No & $0(0)$ & $10(0.6)$ & $1(0.1)$ & 22.915 & 0.028 \\
\hline & Light & $4(0.2)$ & $31(1.8)$ & $6(0.4)$ & & \\
\hline & Middle & $2(0.1)$ & $3(0.2)$ & $4(0.2)$ & & \\
\hline & Above medium & $1(0.1)$ & $2(0.1)$ & $0(0)$ & & \\
\hline & Severe & $2(0.1)$ & $0(0)$ & $0(0)$ & & \\
\hline & Necrosis & $0(0)$ & $2(0.1)$ & $0(0)$ & & \\
\hline
\end{tabular}

Note: CP: Cause of Poisoning, COPD: Chronic obstructive pulmonary disease, CP: Cause of poisoning, NSAI: Non-steroidal antiinflammatory drugs 
$25.6 \%$ of the patients poisoned by non-drug agents were in the SCT group. Grade 1 damage was found to be the most common in SCT and ACT patients in the endoscopic staging of the damage caused by corrosive poisoning (Table 4). Patients with singleagent exposure constituted the majority of the patients in whom mortality was not observed. While no mortality was observed in the suicide group, all patients in whom mortality was observed were in the ACT group. In the non-mortality group, the three most frequently exposed substances were analgesic /antipyretic drugs (46.2\%), antidepressant drugs (20.3\%), anti-cardiac drugs (13.1\%), while the exposed substances in the mortality group were corrosive (50\%), antidiabetic drugs (12.5\%), anticardiac drugs (12.5\%), analgesic/antipyretic drugs (12.5\%) and organophosphates (12.5\%). Endoscopic examination of patients in whom mortality was observed due to corrosive substance ingestion included patients of grade 3A and Grade 3B (Table 5). A single variable regression analysis of the causes of poisoning showed that there was a significant prognostic symptom with sex, age, RDW, MPV, blood sugar and drug-induced intoxications. However, only age, RDW, and MPV were associated with the risk of prognosis of drug-induced intoxications after multivariate regression analysis (Table 6).

Table 4: Chi-square test analysis according to the variables of Cause of Poisoning.

\begin{tabular}{|c|c|c|c|c|c|}
\hline \multicolumn{6}{|c|}{ Cause of Poisoning } \\
\hline & & Accident & Suicide & & \\
\hline & & $n(\%)$ & $n(\%)$ & $\chi^{2}$ & p-value \\
\hline \multirow[t]{2}{*}{ Gender } & Female & $746(44.5)$ & $165(9.8)$ & 329.857 & 0.001 \\
\hline & Male & $297(17.7)$ & $470(28)$ & & \\
\hline \multirow[t]{2}{*}{ Drug intake } & Single & $1031(61.4)$ & $412(24.6)$ & 378.133 & 0.001 \\
\hline & Multiple & $12(0.7)$ & $223(13.3)$ & & \\
\hline \multirow[t]{2}{*}{ Mortality } & No & $1035(61.7)$ & $635(37.8)$ & 4.894 & 0.027 \\
\hline & Yes & $8(2.9)$ & $0(0)$ & & \\
\hline \multirow[t]{10}{*}{ Drugs } & Paracetamol & $182(10.8)$ & $148(8.8)$ & 24.085 & 0.004 \\
\hline & Antidiabetic & $83(4.9)$ & $31(1.8)$ & & \\
\hline & Anticardiac & $130(7.7)$ & $90(5.4)$ & & \\
\hline & Asthma-COPD & $86(5.1)$ & $55(3.3)$ & & \\
\hline & Aspirin & $128(7.6)$ & $94(5.6)$ & & \\
\hline & NSAI & $79(4.7)$ & $41(2.4)$ & & \\
\hline & Antihypertensive & $66(3.9)$ & $36(2.1)$ & & \\
\hline & Antidepressant & $222(13.2)$ & $117(7)$ & & \\
\hline & Organophosphates & $15(0.9)$ & $7(0.4)$ & & \\
\hline & Corrosive & $52(3.1)$ & $16(1)$ & & \\
\hline \multirow[t]{6}{*}{ Corrosive } & No & $9(0.5)$ & $2(0.1)$ & 9.641 & 0.014 \\
\hline & Light & $\begin{array}{l}31(1.8) \\
10(0.6)\end{array}$ & $\begin{array}{l}31(1.8) \\
10(0.6)\end{array}$ & & \\
\hline & Middle & $\begin{array}{l}5(0.3) \\
4(0.2)\end{array}$ & $\begin{array}{l}5(0.3) \\
4(0.2)\end{array}$ & & \\
\hline & Above medium & $3(0.2)$ & $0(0)$ & & \\
\hline & Severe & $2(0.1)$ & $0(0)$ & & \\
\hline & Necrosis & $2(0.1)$ & $0(0)$ & & \\
\hline
\end{tabular}

Table 5: Chi-square test analysis according to the variables of Mortality.

\begin{tabular}{|c|c|c|c|c|c|}
\hline \multicolumn{6}{|c|}{ Mortality } \\
\hline & & No & Yes & & \\
\hline & & $n(\%)$ & $n(\%)$ & $\chi^{2}$ & p-value \\
\hline \multirow[t]{2}{*}{ Gender } & Female & $906(54)$ & $5(0.3)$ & 0.218 & 0.64 \\
\hline & Male & $764(45.5)$ & $3(0.2)$ & & \\
\hline \multirow[t]{2}{*}{ Drug intake } & Single & $1431(85.8)$ & $4(0.2)$ & 8.648 & 0.003 \\
\hline & Multiple & $231(13.8)$ & $4(0.2)$ & & \\
\hline \multirow[t]{2}{*}{$\mathrm{CP}$} & Accident & $1035(61.7)$ & $8(0.5)$ & 4.894 & 0.027 \\
\hline & Suicide & $635(37.7)$ & $0(0)$ & & \\
\hline Drugs & Paracetamol & $330(19.7)$ & $0(0)$ & 54.887 & 0.001 \\
\hline
\end{tabular}




\begin{tabular}{|c|c|c|c|c|c|}
\hline & Antidiabetic & 113(6.7) & $1(0.1)$ & & \\
\hline & Anticardiac & $219(13.1)$ & $1(0.1)$ & & \\
\hline & Asthma-COPD & $141(8.4)$ & $0(0)$ & & \\
\hline & Aspirin & $221(13.2)$ & $1(0.1)$ & & \\
\hline & NSAI & $120(7.2)$ & $0(0)$ & & \\
\hline & Antihypertensive & $102(6.1)$ & $0(0)$ & & \\
\hline & Antidepressant & $339(20.2)$ & $0(0)$ & & \\
\hline & Organophosphates & $21(1.3)$ & $1(0.1)$ & & \\
\hline & Corrosive & $64(3.8)$ & $4(0.2)$ & & \\
\hline \multirow[t]{6}{*}{ Corrosive } & No & $11(0.7)$ & $0(0)$ & 837.075 & 0.001 \\
\hline & Light & $41(2.4)$ & $0(0)$ & & \\
\hline & Middle & $9(0.5)$ & $0(0)$ & & \\
\hline & Above medium & $3(0.2)$ & $0(0)$ & & \\
\hline & Severe & $0(0)$ & $2(0.1)$ & & \\
\hline & Necrosis & $0(0)$ & $2(0.1)$ & & \\
\hline
\end{tabular}

Table 6: Univariate and multivariate Cox regression analyses for predicting the development of cause of poisoning.

\begin{tabular}{|c|c|c|c|c|c|c|c|c|}
\hline \multicolumn{9}{|c|}{ Cause of Poisoning } \\
\hline & \multicolumn{3}{|c|}{ Univariate } & \multicolumn{3}{|c|}{ Multivariate } & \multicolumn{2}{|c|}{ Correlation } \\
\hline & HR & $95 \% \mathrm{Cl}$ & p-value & HR & $95 \% \mathrm{Cl}$ & p-value & $\mathbf{r}$ & p-value \\
\hline Age & 4.238 & $3.611-4.974$ & 0.001 & 4.469 & $3.728-5.358$ & 0.001 & 0.767 & 0.001 \\
\hline RDW & 0.910 & $0.859-1.029$ & 0.001 & 0,847 & $0.755-0.951$ & 0.005 & -0.079 & 0.001 \\
\hline MPV & 1.090 & 0.996-1.193 & 0.061 & 1.227 & $1.041-1.447$ & 0.015 & -0.046 & 0.061 \\
\hline Poison & 0.945 & $0.912-0.980$ & 0.002 & 0.887 & $0.827-0.950$ & 0.001 & -0.075 & 0.002 \\
\hline Gender & 0.140 & $0.112-0.175$ & 0.001 & & & & -0.443 & 0.001 \\
\hline Mortality & 0.000 & $0.000-0.000$ & 0.999 & & & & $-0,054$ & 0.027 \\
\hline ALT & 0.998 & 0.993-1.002 & 0.323 & & & & -0.023 & 0.347 \\
\hline AST & 0.998 & $0.994-1.002$ & 0.348 & & & & -0.024 & 0.321 \\
\hline WBC & 0.992 & $0.966-1.019$ & 0.561 & & & & -0.014 & 0.561 \\
\hline BS & 1.004 & $1.001-1.007$ & 0.020 & & & & 0.057 & 0.020 \\
\hline
\end{tabular}

\section{Discussion}

Poisoning due to accidental or suicidal substance use is one of the important medical conditions frequently encountered in emergency departments. Poisoning, which can lead to permanent disability, serious psychological traumas and fatal consequences, creates difficulties in terms of the multiplicity of causes and the creation of a wide range of age. Anatomical and physiological differences in children lead to different pathologies of poisonings. Factors such as climate, culture, level of development, season, times of the day, gender and age are effective in the exposure of children to poisoning. Accidental poisonings are more common in boys aged 1-5 years due to increased mobility and the development of research and learning curiosity [8]. Accidental poisonings are common in the play age and suicidal poisonings are common in adolescents. $58,1 \%$ of the poisoned patients were under five years of age and the majority of them were boys in the study by Akgül et al. [9] Also, 30.7\% of the poisoned patients were older than twelve years of age and the majority of them were girls. In contrast, the rate of boys over 12 years of age was found to be high in the study by Kondolot et al. [10]
In our study, accidental poisonings were more common in girls, whereas suicidal poisonings were more common in boys. Unlike the literature, this high rate suggests that parents or caregivers being more careful in childcare may cause less accidental poisoning in the under-five age group. This high rate between the ages of 6-11 maybe because children are in an age range where they gain more autonomy and are less controllable. In general, $85-90 \%$ of children poisonings were accidental and 10-15\% were suicidal [11,12]. Studies are showing that suicidal poisonings are more common in adolescent girls $[13,14]$. In the study of Tekerek et al. [15], suicidal poisonings were frequently seen in girls and accidental poisonings were frequently seen in boys, whereas most of the poisonings were seen to be accidental. In the literature, suicidal poisoning cases increase with age. Greene reported in his study that suicidal behaviors were not present in those younger than 6 years of age and that suicide was quite rare between the ages of 6-12 [16]. In our study, $23.3 \%$ of suicidal poisonings were in the range of $6-11$ years, $76.7 \%$ were patients aged 12 years and older.

Also, no suicidal cases were detected in patients younger than five years of age. The most frequent suicidal poisoning was found 
in $470(74 \%)$ boys. The most frequent agent used for the suicidal purpose was paracetamol and the second was antidepressants. Poisoning agents were mostly peroral drugs and cleaning products that were easily accessible to children $[17,18]$. It was reported that the most common poisonings were by paracetamol in separate studies by Kondolot et al. $[10,19]$, by central nervous system drugs in the study by Bucak et al. [20] and by nonsteroidal antiinflammatory agents in the study by Baş et al. [21,22] reported that $71 \%$ of poisonings were by drugs and $18.9 \%$ were by organophosphate pesticides. It can be thought that the difference in these studies depends on the social structure and life as well as dealing with agriculture. In our study, the most common poisonings were found to be by analgesics/antipyretics (the most common of them was paracetamol) between the ages of 1-5, by antidepressants between the ages of 6-11 and by analgesics/antipyretics over 12 years of age.

The increase in the frequency of antidepressant poisoning may be because the population is more comfortable to consult a doctor for psychiatric disorders and the access of children to antidepressant drugs that are increasingly used as a result of the increase in such problems throughout the society. Poisoning can occur by taking one type of agent or multiple agents at the same time. In a study by Fuller et al. [23], it was found that there was multiple drug ingestion in $50 \%$ of all poisoning cases. In the study of Karcioğlu et al. [24], 53.6\% of the poisonings were by single drug and $46.4 \%$ were by multiple drugs, whereas in the study of Kaygusuz et al. [25], 41.2\% of the cases were poisoned by single drug and $53.5 \%$ were by multiple drugs. In our study, it was found that 1031 (61.4) of the patients who were accidentally poisoned were exposed to a single drug, $12(0.7)$ of them were exposed to multiple drugs and 412 (24.6) of the suicidal poisonings occurred with single drug exposure, 223 (13.3) of them occurred with single drug exposure. The use of multiple drugs in suicides of children aged 12 years and older are especially noteworthy. The ingestion of corrosive substances is usually of an accidental origin [26].

It was found that children under the age of 5 years constituted a high-risk group in accidental ingestion, it peaked at the age of 2 years, and it was most commonly seen in boys [27]. Corrosive esophagitis is the most common condition caused by corrosive substances and stricture develops as the most frequent complication [26]. In the study by Koç et al. [28], 40.3\% of the cases were evaluated as clinically normal and $63.1 \%$ of 46 cases with pathological findings were found to have hyperemia in the oropharynx. In the study of Karaaslan et al. [27], esophagoscopy was performed in $1 / 4$ of the cases and changes were detected in the esophagus ranging from grade 1 to grade $2 \mathrm{~b}$. In a study by Kutlu et al. [29], it was observed that the esophagus was affected at different levels in $73.6 \%$ of the cases undergoing endoscopy. In our study, poisonings by corrosive substances were found most frequently between the ages of 6-11 and most of them were accidental ingestions. Poisoning by corrosive substances was found to be much lower in our series compared to similar studies $(4.2 \%)[3,10]$. This may be thought to be the result of public awareness of the potential dangers of children's access to cleaning agents and the fact that they are becoming more careful.

However, the fact that $50 \%$ of the deaths in our series is the result of complications due to the ingestion of caustic substance shows that studies should be conducted to raise awareness on this issue. Keeping cleaning agents in a locked place out of the reach of children and extending the use of smart lids in packages containing cleaning agents will be beneficial in preventing poisoning by such substances. While the mortality rate is low in developed countries in poisonings, it is still very high in developing countries. The mortality rate in poisoning cases varies between $0.1 \%$ and $3.9 \%$ [30]. In the United States [31], the mortality rate was reported to be $2 \%$ in patients younger than 6 years, $0.06 \%$ between $6-12$ years and $5.6 \%$ between $13-19$ years of age. The mortality rate was found as $0.4 \%$ in the UK [32]. Poisoning-related deaths were reported in $2.5-13.6 \%$ in Pakistan [33] and $8.9 \%$ in India [34]. The rate of poisoning-related deaths in Turkey ranges from $0 \%$ to $5 \%$ [10]. In our study, the mortality rate was $0.5 \%$ and the recovery rate was $99.5 \%$. This mortality rate was found to be quite low compared to the studies conducted in our region in the past years [35].

Four of the eight cases in whom mortality was observed were due to corrosive substances and four cases were due to aspirin, antidiabetic, anti-cardiac and organophosphate poisonings. All of the causes of mortality due to drug poisoning were very late admissions to the hospital. Improvements in diagnosis and treatment may be the main reason for the decrease in mortality rate. Most of the poisonings are asymptomatic and only supportive treatment is provided. However, the main treatment is the implementation of the approach to the emergency patient protocol. Besides, it is in the form of preventing or reducing the absorption of the active substance, administering systemic antidotes, if any, altering the metabolism of the active substance, accelerating excretion from the body, and treatment according to findings [9]. In the study in Spain, it was reported that $61.3 \%$ of the patients were admitted to the hospital within one hour after ingestion of toxic substances, $10.3 \%$ were treated before admission, $83.3 \%$ were discharged from the emergency department and $15.2 \%$ were followed by hospitalization; $1.5 \%$ were followed in the intensive care unit $[22,36]$ reported that $87 \%$ of patients admitted with poisoning were discharged from the emergency department and mortality was $0.03 \%$.

In our study, similar treatment in the literature was performed in the emergency department [9]. To decrease the absorption, gastric lavage was applied to $61 \%$ and activated charcoal was applied to $79 \%$ of the patients who admitted to the hospital in the first hour. Also, the systemic antidote for the active substance was given after the first intervention, if any. 83\% of the cases were hospitalized and the others were followed up in the emergency department. In patients who came after poisoning by corrosive substance, hyperemia in the oral mucosa which is the first sign of poisoning, 
inability to swallow saliva, burn marks on the lips and tongue were searched. Endoscopic procedure was applied to patients who gave consent to detect esophageal burn. Grade 0 patients without any burns were discharged without medical treatment. Medical treatment was initiated in patients with burns according to the degree of burn. The degrees of burn were detected as $3 \mathrm{~A}$ and 3B in 4 patients in whom mortality was observed due to corrosive substances. Careful follow-up and treatment of these patients are necessary as the corrosive substance is an important cause of mortality. It is of utmost importance to take measures to prevent children from accessing these substances and to organize programs to raise awareness of families. The most important constraint in the study was that it was retrospective. Other important constraints were the limited retrieval of information due to the difficulty in reaching data and patient relatives.

\section{Conclusion}

Although deaths due to poisoning have decreased in recent years, the increase of poisoning cases is an important health problem. It is thought that the expansion of health care services and easy access are effective in reducing deaths. Because accidental poisonings are in the majority in developing countries and may result in death, we believe that the main solution is education despite the improvements in the diagnosis and treatment of poisonings. It is important for public health that the primary objective is to take measures to prevent poisoning, to raise awareness of the families and to make the use of smart lids compulsory. The effective use of the National Poison Information Centers will ensure faster and more accurate post-poisoning treatment.

\section{Acknowledgements}

None declared

\section{Authorship}

The conception and design of the work; the acquisition analysis, and interpretation of data for the work; drafting the work and revising it critically for important intellectual content; and final approval of the manuscript was done by Abuzer Coşkun, MD, and Cengiz Güney, Assoc. Prof

\section{Funding}

None declared.

\section{Availability of data and materials}

All data is available on request without restriction.

\section{Conflict of interest}

None declared.

\section{Informed consent}

Written informed consent was not necessary because the study was performed retrospectively by screening patient files.

\section{Ethical approval}

The study was approved by the institutional review board (Decision No:2019-07/27 Data:04.07.2019).

\section{Human rights}

The study was made in following the Declaration of Helsinki for Human Research.

\section{References}

1. Rodgers GC, Matyunas NJ (2004) Poisonings: Drugs, chemicals, and plants. In: Behrman RE, Kliegmen RM, Jenson HB (edn's). Nelson Textbook of Pediatrics. Philadelphia, WB Saunders 2362-2374.

2. Sarıkayalar F (2001) Poisonings. Contribution Journal of Pediatrics 22: 377-395.

3. Sumer V, Guler E, Karanfil R, Dalkıran T, Gursoy H, et al. (2011) Evaluation of the poisoning cases who applied to the pediatrics emergency unit. Turk Arch Ped 46: 234-240.

4. Özayar E, Değerli S, Güleç H, Şahin Ş, Dereli N, et al. (2011) Retrospective Analysis of Poisoning Cases Admitted to Intensive Care Unit. J of Intensive Care 3: 59-62.

5. Jepsen F, Ryan M (2005) Poisoning in children. Curr Pediatr 15: 563-568.

6. Soori H (2001) Developmental risk factors for unintentional childhood poisoning. Saudi Med J 22: 227-230.

7. Zargar SA, Kochhar R, Mehta S, Mehta SK (1991) The role of fiberoptic endoscopy in the management of corrosive ingestion and modified endoscopic classification of burns. Gastrointest Endosc 37(2): 165-169.

8. Biçer S, Sezer S, Çetindağ F, Kesikminare M, Tombulca N, et al. (2007) Evaluation of Acute Poisoning Cases in Pediatric Emergency Clinic 2005. Marmara Med J 20: 12-20.

9. Akgül F, Er A, Çelik FÇ, Çağlar A, Ulusoy E, et al. (2016) Retrospective Analysis of Childhood Poisoning. J Pediatr Emerg Intensive Care Med 3: 91-96.

10. Kondolot M, Akyıldız B, Gürözen F, Kurtoğlu S, Patıroğlu T, et al. (2009) Evaluation of poisoning cases brought to pediatric emergency department. J of Child Health and Diseases 52: 68-74.

11. Öner N, İnan M, Vatansever Ü (2004) Poisoning in children in the Trakya Region. Turkish Archives of Pediatrics 39: 25-30.

12. Akbay ÖY, Uçar B (2003) Retrospective evaluation of childhood poisoning in region Eskişehir. J of Child Health and Diseases 46: 103-113.

13. Watson WA, Litovitz TL, Klein Schwartz W (2004) 2003 Annual Report of the American Association of Poison Control Centers Toxic Exposure Surveillance System. Am J Emerg Med 22: 335-404.

14. Mokhlesi B, Leiken JB, Murray P, Cordbridge TC (2003) Adult toxicology in critical care. Part I: General approach to the intoxicated patients. Chest 123: 577-592.

15. Tekerek NÜ, Dursun A, Akyıldız BN (2016) Retrospective Analysis of Poisoning Cases Our Followed in Pediatric Intensive Care Unit. J Pediatr Emerg Intensive Care Med 3: 21-26

16. Greene Dorothea B (1988) Chıldhood suicıde and myths surrounding it 'Social Work' 39(2): 330-332.

17. Sahin S, Carman KB, Dinleyici EC (2011) Acute poisoning in children data of a pediatric emergency unit. Iran J Pediatr 21(4): 479-484.

18. McGuigan MA (1999) Common culprits in childhood poisoning: epidemiology, treatment and parental advice for prevention. Paediatric Drugs 1: 313-324 
19. Mintegi S, Fernandez A, Alustiza J, Canduela V, Mongil I, et al. (2006) Emergency visits for childhood poisoning: a 2-year prospective multicenter survey in Spain. Pediatr Emerg Care 22(5): 334-338.

20. Bucak iH, Turgut M, Tümgör G, Eynallı A (2015) Evaluation of childhood drug poisoning in a tertiary hospital in Çukurova region between 2006 and 2010. Turkish J Pediatr Dis 2: 124-130.

21. Baş VN, Şahiner ÜM, Aslan B, Altuner Torun Y (2015) Poisoning in childhood: A single instution's experience. Turkish J Pediatr Dis 3: 198202.

22. Akbaba M, Nazlican E, Demirhindi H, Sütoluk Z, Gökel Y, et al. (2007) Etiological and demographical characteristics of acute adult poisoning in Adana, Turkey. Hum Exp Toxicol 26: 401-406.

23. Fuller GN, Rea AJ, Payne JF, Lant AF (1989) Parasuicide in central London 1984-1988. J R Soc Med 82(11): 653-656.

24. Karcıoğlu Ö, Demirel Y, Eser Z, Özer I, Salama M, et al. (2002) Drug Poisoning in Emergency Department: One - Year Case Series. Turkey Emerg Med J 2: 26-33.

25. Kaygusuz K, Gürsoy S, Kılıçcıoğlu F, Özdemirkol i, Mimaroğlu C, et al (2004) Retrospective Analysis of Cases Followed with the Diagnosis of Acute Drug Poisoning in the Intensive Care Unit of Cumhuriyet University Medical Faculty Hospital between 1998-2004. Cumhuriyet Med J 26: 161-165.

26. Huang YC, Hsuan Ni Y, Shiee Lai H, Hwei Chang M (2004) Corrosive esophagitis in children. Pediatr Surg Int 20: 207-210.

27. Karaarslan B, Turla A, Aydın B (2007) Ondokuz Mayıs University Faculty of Medicine Emergency Department. Van Med J 14(4): 109-113.

28. Koç O, Karaman A, Karaman i, Erdoğan D, Çavuşoğlu YH, et al. (2003) How should children approach bleach. J of the Turkish Association of Pediatric Surgeon 17(2): 70-73.

ISSN: 2574-1241

DOI: $10.26717 /$ BJSTR.2020.27.004538

Abuzer Coskun. Biomed J Sci \& Tech Res

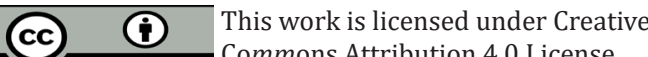

Submission Link: https://biomedres.us/submit-manuscript.php
29. Kutlu T, Erkan T, Çullu F, Yavuz A, Taştan Y, et al. (2002) Corrosive substances in children: 10 years of experience. Abstract Book, Oral Presentation. $38^{\text {th }}$ Turkish Pediatrics Congress, 2002.

30. Dorado Pombo S, Martín Fernández J, Sabugal Rodelgo G, Caballero Vallés PJ (1996) Epidemiology of acute poisoning: study of 613 cases in the Community of Madrid in 1994. Rev Clin Esp 196(3): 150-156.

31. Bronstein AC, Spyker DA, Cantilena LR, Green JL, Rumack BH, et al. (2009) 2008 Annual Report of the American Association of Poison Control Centers' National Poison Data System (NPDS): 26th Annual Report. Clin Toxicol (Phila) 47(10): 911-1084.

32. Manzar N, Saad SM, Manzar B, Fatima SS (2010) The study of etiological and demographic characteristics of acute household accidental poisoning in children-a consecutive case series study from Pakistan. BMC Pediatr 10: 28

33. Even KM, Armsby CC, Bateman ST (2014) Poisonings requiring admission to the pediatric intensive care unit: A 5-year review. Clin Toxicol (Phila) 52: 519-524.

34. Jayashree M, Singhi S (2011) Changing trends and predictors of outcome in patients with acute poisoning admitted to the intensive care. J Trop Pediatr 57(5): 340-346.

35. Ergür AT, Sütçü İ, Tanzer F (1999) Evaluation of poisoning cases in our pediatric ward: 1990-1998. Tur Klin Ped 8: 9-14.

36. Nalliah RP, Anderson IM, Lee MK, Rampa S, Allareddy V, et al. (2014) Children in the United States make closeto 200,000 emergency department visits due to poisoning each year. Pediatr Emerg Care 30: 453-457.

$\begin{array}{ll}\text { BIOMEDICAL } & \text { Assets of Publishing with us } \\ \text { RESEARCHES } & \text { - Global archiving of articles } \\ \text { - Immediate, unrestricted online access } \\ \end{array}$

